\title{
Analysis Characteristics of Antawacana as Reflections on the Character of Werkudara in Wayang Purwa
}

\author{
T B Widagdo ${ }^{1}$, Djatmika $^{2}, \mathrm{H}_{\text {Y }}$ ustanto $^{3}$ \\ \{1bayutitis9@gmail.com,2djatmika@uns.ac.id, ${ }^{3}$ henryyustanto@yahoo.com\} \\ ${ }^{1,2,3}$ Study Program of Descriptive Linguistic, Postgraduate, Sebelas Maret University
}

\begin{abstract}
Wayang kulit purwa is a Javanese culture that is still maintained its existence until now. This existence is inseparable from the use of a variety of beautiful languages in each of its performances. One special form of language variation can be found in the antawacana section or characteristic of character dialogue. One figure who is unique in conducting antawacana is the Werkudara figure. Werkudara has a characteristic, namely the use of a variety of ngoko languages in each of its speeches. The uniqueness also reflects the original character of Werkudara. For this reason, this study uses a stylistic study to explore more deeply how the character of Werkudara by analyzing the language style used by Werkudara when conducting antawacana. The descriptive qualitative method was used in this study to provide a deep explanation of the linguistic phenomenon of Werkudara figures. The results of this study are, 1) utilization of purwakanthi swara or assonance $/ \mathrm{a} /$ and $/ \mathrm{J} /$ in each antawacana, 2) the use of purwakanthi sastra or alliteration /p/ plosive sound, 3) the use of purwakanthi lumaksita as an affirmation of meaning, and 4) the use a variety of ngoko languages to fellow humans, and 5) the use of a variety of krama languages to Dewa Ruci. These characteristics imply the character of Werkudara as a figure who is firm, courageous, straightforward, obedient, and respectful.
\end{abstract}

Keywords: Antawacana, Werkudara, Stylistic, Purwakanthi, variety of languages (unda-usuk)

\section{Introduction}

Wayang kulit purwa is a Javanese culture that still exists today. Wayang purwa is a puppet that takes the story from the Mahabarata and Ramayana books [1]. in opinions about the recent developments in the performance of the javanese shadow puppet theater (wayang kulit purwa) vary greatly [2]. Wayang kulit purwa is also classified as a culture that has a high aesthetic quality. these high-quality and complex culture of wayang, because it includes various fused art forms; includes literary arts, languages, drama, music, dance, fine arts, etc [3]. Based on the various constituent elements of the aesthetic quality of puppet performances, this study focuses on one of the constituent elements of the aesthetic quality of puppet performances, namely the use of various languages. The variety of languages used in puppet shows is divided into two, ordinary language and poetic language variations, the local terms 
are basa lumrah (ordinary language) and basa endah [4]. Furthermore, the language used in puppetry is the highest variety of languages. Then in detail, the language used in puppet shows is in several parts (antawacana 'character talk style', kandha 'narration', and suluk 'singing of puppeteers') [1]. Puppeteers are required to have more expertise in the field because it is the soul of a puppet show.

Previous research also touched on the beauty of language in wayang kulit performances such as [3], [5], [2], [6]. The research explains the beauty of wayang languages including suluk, kandha, and antawacana. But in this study, the touchpoints were not deep enough in the aspects of puppet language. For this reason, the researcher will present research that focuses on a single point, namely antawacana, which will be examined in detail and in-depth.

This research will discuss in more detail about antawacana. Antawacana is also a symbol of the character that distinguishes one puppet character from another puppet character in a puppet performance [1]. Besides that, Antawacana is considered important to be explored more deeply because antawacana is soul of performance of wayang purwa and also as a parameter of a puppeteer who can be judged as a good or bad puppeteer.

One of the puppet figures who have unique antawacana characteristics is the Werkudara character. Werkudara has a different characteristic when doing antawacana, which is not by binding rules like other figures [1]. Werkudara in antawacana always uses basa ngoko or ngoko language. Werkudara in the puppet staging as a brave hero has a straightforward and firm character, However, Werkudara was also shown as someone who seemed impolite [7]. From the uniqueness, the research on aesthetic of languages in wayang purwa, especially about antawacana Werkudara, is very interesting to do.

The stylistic approach was used in this study as a scalpel, to reveal the style or characteristics of the Werkudara character figures. Stylistics is a linguistic discipline that pays attention to the style of language and the beauty of the language used in literary works. The study of stylistics is an interdisciplinary science between linguistics and literature [8]. On the other hand said that stylistics did not just stop with textual analysis, but must analyze even more complex things, i.e. 'Discourse analysis [9]. Meanwhile, stylistic theory examines the characteristics of language use in literary discourse, features that distinguish or contrast it with non-literary discourse, examining the deviation of grammar as a literary tool [10].

Furthermore, Stylistics revealed to two approaches to learning language styles. The first approach begins with a systematic analysis of the linguistic system of literary works, followed by an interpretation of its characteristics seen from the aesthetic purpose of the work as "total meaning". The second approach is to study several characteristics that distinguish one system from another to show deviations and distortions to find the aesthetic purpose of literary works [11]. By using force theory, researchers can reveal antawacana style and character of Werkudara characters based on the usage style of purwakanthi swara or assonance (use of vocal sounds), purwakanthi sastra or alliteration (use of consonant sounds), purwakanthi lumaksita (repetition of words or phrases in sentences) and patterns of variance language or undha-usuk that characterizes Werkudara in antawacana

By using these theories, researcher can reveal the antawacana style and character of Werkudara based on the usage style of purwakanthi swara or assonance (use of vocal sounds), purwakanthi sastra or alliteration (use of consonant sounds), purwakanthi lumaksita (repetition of words or phrases in sentences) and patterns of variance or unda-usuk language that characterizes Werkudara in antawacana. 


\section{Research Method}

This research entitled 'Analysis of Antawacana Characteristics as Reflections on the Characteristics of Werkudara (Stylistic analysis)' uses a qualitative method. That the qualitative method is a research procedure that produces descriptive data in the form of written or oral words from people and observed behavior [12]. This research seeks to enter the world of the data under study, then understand and try to systematize and describe the object under study, namely Werkudara antawacana.

The data source used in this study was the recording of wayang with Dewa Ruci's play by Ki Nartosabdo. This choice has the reason that Ki Nartosabdo is a puppeteer legend in Indonesia who has an extraordinary ability to distinguish the voices of one character with another. The data used in this study is the antawacana Werkudara in Dewa Ruci's play by Ki Nartosabdo. The technique of providing data in Nartosabdo's research is the technique of listening and taking notes. listening technique is a technique by listening to the use of language [13]. In this study listening techniques are used to listen to the use of language that is suspected as data in the recording of wayang performances by the drama Dewa Ruci (1984) by Ki Nartosabdo. After the listening process was carried out, the researchers then wrote data with orthographic transcription and phonetic transcription for alliteration and assonance data. Then analyzed based on the research objectives.

\section{Results And Discussion}

\subsection{Utilization of Purwakanthi}

One of the peculiarities found in the antawacana of the most dominant Werkudara figures is the use of Purwakanthi. Purwakanthi is sound repetition to be tunable [3]. Purwakanthi in Javanese is divided into three, namely asonance or purwakanthi swara 'vowel sound equality', alliteration or Purwakanthi sastra 'equality of consonant sounds in the formation of words and sentences', and Purwakanthi lumaksita 'repetition of syllables or words used in sentences'. The following are the findings of the purwakanthi which characterize the antawacana figures of the Werkudara character in Dewa Ruci's play by Ki Nartosabdo.

Data 1

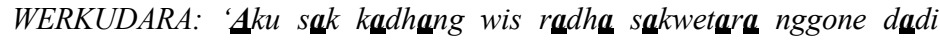
siswaning pandita Durna/ pirang-pirang kanuragan luwih-luwih babagkan olah gegaman kabeh wis podo tuwuk nganti turah- turah mungguh wulange bapa Durna//',

'me and my brothers have long been students of Pandita Durna, some martial arts and weapons knowledge is

Data 2 enough, even to the point of being excessive

WERKUDARA: 'prastawa dawuh paduka pikulun/palilakno aku jaluk pamit//'.

Data 3

'It's clear that all of your advice, please let me say goodbye.'

WERKUDARA: 'anggen kula anregem andalan sampurnanning dumadi/ jare kedah kula angulari wujud arerupa Tirta 


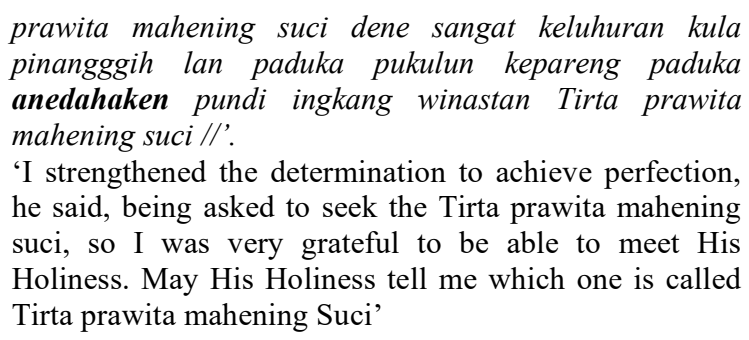

Data (1) above if transcribed as follows [aku sa? kadal] wIs rada sa Jwatar J yg One siwaniy pandita durna, piray-piray kanuragan luwIh-luwIh babakan olah gagaman wIs pJdJ tuwUP yanti turah-turah muygUh wulaye bapa durna] The repetition of voice /a/ and /O dominant is used in antawacana of Werkudara. Purwakanthi /a/ and /O/ provides a reflection of clarity of speech which means that Werkudara has a Werkudara has a firmly and courageous character like the Javanese phrase tanpa tedhing aling-aling or 'someone who has never covered up something from himself'.

Data (2) illustrates consonant repetition or purwakanthi sastra /p/. sound repetition / $\mathrm{p} /$ is a type of sound which is a plosive type of sound. Phonemes / $\mathrm{p} /$ including plosive phonemes [14]. This reflects that the character of Werkudara is a figure who is eager to achieve life goals and is not afraid of anything that stands in his way. Following transcription from antawacana (2) [Prast Jw J dawUh paduk J pikulUn palilakn J aku jalUk pamIt].

Data (3) found repetition of words with a-affixes. Use of the prefix $a$-indicates 'activity to do something'. The sentence pattern shows the regularity of the choice of words used by Werkudara in antawacana with Dewa Ruci. From the pattern above gives meaning to the character of Werkudara always has a strong determination in achieving something.

\subsection{Variety of Languages or Unda-Usuk Antawacana Werkudara}

Each puppet character has its own variety of language variations in conducting antawacana, one of which is the character of Werkurada. Werkudara character is a puppet character who never uses soft language against anyone [3]. During his life he only spoke softly, namely to Dewa Ruci. In various plays, one of them is Dewa Ruci play, Werkudara is confronted by various figures including Durna, Duryudana, Kunthi, Rukmuka, Rukmukala, Bethara Bayu, and Dewa Ruci. From the data obtained can be described two basic patterns in the selection of languages or unda-usuk, namely, Werkudara uses ngoko when confronted with fellow human beings whoever and Werkudara uses krama only when faced with Dewa Ruci. The following detailed explanation.

The variety of languages commonly used by Wekudara figures are the antyabasa ngoko. Ngoko antyabasa is a variety of ngoko languages that result from the use of ngoko words, phrases and affixations, except for words referring to the speech partner using a combination of krama and krama inggil [1]. This was demonstrated by the combination of various ngoko languages, ngoko affixations, and krama which are also used in Werkudarara antawacana. Next is the discussion between Werkudara with Durna and Kunthi in Dewa Ruci's play by Ki Nartosabdo.

Data 4

WERKUDARA: Aku sak kadhang wis radha sakwetara nggone dadi siswane Pandita Durna/pirang-pirang kanuragan luwih-luwih babagkan olah gegaman kabeh wis 
podo tuwuk Nganti turah-turah mungguh wulange bapa durna/nanging ono sawiji maneh ingkang tak suwun reh ning dumadi mono kabeh ono andadekake bisane dumadi iku dadi sampurno yen to aku wes kedunungan opo lan mbok yoa bapa durna kepareng marsita kawruhku apa ngelmu sampurno dumadi/Cara apa kang tak tindakake ojo nganti kurang lebdo gonku nindaake//'.

'I and my brothers have long been students of Pandita Durna, some martial arts and weapons knowledge is enough, even to the point of being excessive but there is one more thing I want to ask for how to achieve the perfection of life. I can be perfect if I do what. And I beg Father Durna to give me insight into how to be perfect, and how to

Data (5) do it'

WERKUDARA: 'Aku bali marang negara ngamarto/ sabab gonku kepengen jangkepi tata krama//'. Ps(JNg)Rs(WR-K)1

'I returned to Ngamarta because I wanted to obey manners'

Antawacana data (4) and (5) conducted Werkudara to teachers and their mothers. Antawacana does not bring up different languages. The variety used in the antawacana is a combination of various ngoko languages and various krama. However, if observed more specifically there is a combination of the ngoko vocabulary, the affixation of the ngoko with the krama vocabulary, from these the variance is classified into ngoko antyabasa.

Variety of antyabasa ngoko in antawacana (4) and (5) can be seen in the use of ngoko lexicon, affixation, and ngoko clitika. In antawacana (4) ngoko lexicon that is used such as 'luwih-luwih 'more', Kabeh 'all', babagkan 'about', turah-turah 'excessive'. In addition to the ngoko lexicon used in antawacana (4) and (5) there is also an affixation of ngoko which is the suffix -e in the words nggone 'by', wulange, 'teaching'.

Then the suffixes in the words andadeake 'make', nindaake 'do', and dawuake 'are discussed'. The suffix-ake in the lexicon shows the meaning of 'intentional deeds' which shows that the Werkudara really wants to do everything the teacher has assigned to get the science of perfection in life. from the use of affixes attached to the krama lexicon, it can be concluded that the ngoko used is the ngoko antyabasa. The use of the variety of ngoko antyabasa in each of the antawacana of the Werkudara figure reflects the character that is firmly, brave, straightforward, and respectfull. Furthermore, the pattern of krama language is shown by the character of Werkudara in the antawacana with Dewa Ruci in Dewa Ruci's play by Ki Nartosabdo.

Data 6

WERKUDARA: 'Inggih ngestokaken dhawuh/ Sadereng lan sasampunipun titah pujangkara pun Werkudaral ngaturaken sungkeming pangabekti kula/ mawantu-wantu kunjuka paduka Sang Bathara/ inggih Sang Marbudengrat//'

'Yes, my majesty before I convey my respect and devotion, may it be conveyed to the majesty of the Bathara, the Lord of the universe" 
Variety of Javanese krama is very thick in antawacana Werkudara with Dewa Ruci (6), the krama lexicon is found on the word saderenge 'before', sampunipun 'afterwards', pangabekti ' loyalty', kula 'I', kunjuka 'directed'. the affix of krama is seen in the space above, namely the suffix-aken in the word ngestokaken 'respectful speech, ngaturaken 'convey'. Krama lexicon is present in the type of verbs or verbs relating to obedience and submission to the Almighty. So in the analysis of the antawacana characteristics of the Werkudara character, it provides a novelty in linguistic research, especially in the wayang purwa performances. With this research, the characteristics of the characters can be explained by an in-depth analysis of the language as symbols. And it also shows that the beauty of language in the wayang purwa performance is not only in the level of suluk or kandha, but also in the level of antawacana can also be explained the beauty and uniqueness of the use of language.

\section{Conclusion}

Werkudara is a character who has a very striking characteristic than other figures. This can be traced from the characteristic in their antawacana. In this study found the characteristics and character of Werkudara are, 1) utilization of purwakanthi swara or assonance / a / and / D / in each antawacana, 2) the use of purwakanthi sastra or alliteration /p/plosive sound, 3) the use of purwakanthi lumaksita as an affirmation of meaning, and 4) the use of various ngoko to fellow humans, and 5) the use of various krama to Dewa Ruci. From these characteristics implies the character of Werkudara as a figure who is firmly, courageous, straightforward, obedient, and respectful.

\section{References}

[1] Poedjoesoedarmo, Ragam Panggung dalam Bahasa Jawa. Jakarta: Pusat Pembinaan dan Pengembangan Bahasa, 1986.

[2] J. Mrazek, Javanese Wayang Kulit in the Times of Comedy: Clown Scenes, Innovation, and the Performance's Being in the Present World. New York: Cornell University Press, 1999.

[3] I. Sutardjo, Keindahan Bahasa Pedalangan. Solo: FSSR Publishing, 2010.

[4] Padmosoekotjo, Ngengrengan Kasusastran Djawa I, II. Yogyakarta: Hien Hoo Sing, 1960.

[5] B. Arps, Tall tree, nest of the wind: The Javanese shadow-play Dewa Ruci performed by Ki Anom Soeroto: A study in performance philology. Netherland: Brill, 2017.

[6] E. Kadarisman, Mengurai Bahasa Menyibak Budaya Bunga Rampai Linguistik, Puitika, dan Pengajaran Bahasa. Malang: UIN-Maliki Press., 2013.

[7] A. Wahyudi, Lakon Dewa Ruci: Cara Menjadi Jawa. Yogyakarta: Bagaskara, 2012.

[8] H. Kridalaksana, Kamus Linguistik. Jakarta: PT Gramedia, 2011.

[9] Widdowson, Stylistics and Teaching of Literature. London: Longman, 1997.

[10] Sudjiman, Bunga Rampai Stilistika. Jakarta: Pustaka Utama Grafiti., 1993.

[11] Sumarlam, Stilistika: Teori, Kajian, dan Pembelajaran. Solo: Bukukatta, 2018.

[12] L. Moleong, Metodologi Penelitian Kualitatif: Edisi Revisi. Bandung: PT Remaja Rosdakarya, 2013.

[13] Sudaryanto, Metode Aneka Teknik Analisis Bahasa Pengantar Penelitian Wahana Kebudayaan Secara Linguistis. Yogyakarta: Duta Wacana University Press, 1993.

[14] M. Muslich, Fonologi: Bahasa Indonesia. Jakarta: PT Bumi Aksara, 2012. 